\title{
Correction to: Enhanced TOA Estimation Using OFDM over Wide-Band Transmission Based on a Simulated Model
}

\author{
Huthaifa A. Obeidat ${ }^{1}$ (D) . Imran Ahmad ${ }^{2}$. Mohammad R. Rawashdeh ${ }^{3}$. \\ Ali A. Abdullah ${ }^{2}$. Wafa S. Shuaieb ${ }^{4}$. Omar A. Obeidat ${ }^{5} \cdot$ Raed A. Abdallhameed $^{2,6}$
}

Published online: 20 December 2021

(C) The Author(s) 2021

\section{Correction to: Wireless Personal Communications https://doi.org/10.1007/s11277-021-09297-z}

In this article the author name Huthaifa A. Obeidat was incorrectly written as Huthaifa A. Obeidatat.

The original article has been corrected

Open Access This article is licensed under a Creative Commons Attribution 4.0 International License, which permits use, sharing, adaptation, distribution and reproduction in any medium or format, as long as you give appropriate credit to the original author(s) and the source, provide a link to the Creative Commons licence, and indicate if changes were made. The images or other third party material in this article are included in the article's Creative Commons licence, unless indicated otherwise in a credit line to the material. If material is not included in the article's Creative Commons licence and your intended use is not permitted by statutory regulation or exceeds the permitted use, you will need to obtain permission directly from the copyright holder. To view a copy of this licence, visit http:// creativecommons.org/licenses/by/4.0/.

The original article can be found online at https://doi.org/10.1007/s11277-021-09297-z.

Huthaifa A. Obeidat

h.obeidat@jpu.edu.jo

1 Faculty of Engineering, Jerash University, Jerash, Jordan

2 Faculty of Engineering and Informatics, University of Bradford, Bradford, UK

3 Faculty of Engineering, Yarmouk University, Irbid, Jordan

4 Faculty of Engineering Omar, Al-Mukhtar University, Al Beida, Libya

5 College of Engineering, Wayne State University, Detroit, MI, USA

6 Basra University College of Science and Technology, Basra 61004, Iraq 
Open Access This article is licensed under a Creative Commons Attribution 4.0 International License, which permits use, sharing, adaptation, distribution and reproduction in any medium or format, as long as you give appropriate credit to the original author(s) and the source, provide a link to the Creative Commons licence, and indicate if changes were made. The images or other third party material in this article are included in the article's Creative Commons licence, unless indicated otherwise in a credit line to the material. If material is not included in the article's Creative Commons licence and your intended use is not permitted by statutory regulation or exceeds the permitted use, you will need to obtain permission directly from the copyright holder. To view a copy of this licence, visit http://creativecommons.org/licenses/by/4.0/.

Publisher's Note Springer Nature remains neutral with regard to jurisdictional claims in published maps and institutional affiliations. 